\title{
EDITORIAL Turning on the taps
}

npj Clean Water (2018)1:4; doi:10.1038/s41545-

018-0007-9

A ready supply of clean water is critical for producing the food, energy, and products that modern society needs in order to survive and thrive, in addition to being key for safe guarding human health and the natural environment. The United Nations recognized this by making clean water and sanitation a Sustainable Development Goal. ${ }^{1}$ While water covers about twothirds of the planet, $\sim 97 \%$ of this is saline water in oceans, seas, and bays, and thus cannot be used in its natural form, while less than $0.8 \%$ is fresh and accessible for use. ${ }^{2}$

Global fresh water withdrawls have been estimated at about $4000 \mathrm{~km}^{3}$ per year, ${ }^{3}$ which is about $7 \%$ of the global renewable fresh water supply. This means that if our fresh water withdrawls were only used once and then disposed of, our fresh water supplies would last only 14 years. This dilemma defines the "clean water gap", which underscores the importance of maintaining natural water supplies so that they can be used, and in efficient processing of wastewater. About $70 \%$ of wastewater is treated globally, but only $4 \%$ is reused and most is ocean discharged and not immediately reusable. ${ }^{4}$ However, were advanced treatments applied to enable reuse of the $70 \%$, assuming adequate water quality could be achieved, it would increase the lifetime of our fresh water reserves to almost 50 years. Desalination is an obvious option and has been employed in Middle East, North African, and Mediterranean countries for over half a century. So, water reuse and desalination are viable, but at relatively high cost, energy demand and carbon footprint, due to predominant energy supplies still deriving from combustion of fossil fuels. The "clean water gap" remains, and the most likely solutions are advanced water treatment processes and effective water resource management.

The good news is that nature provides world's first and longest operating renewable-powered desalination and water reuse plant: solar evaporation of ocean water, transported by wind over the land and falling by gravity back to the Earth as fresh water. Indeed, we can learn much from nature, and there has been significant emphasis on mimicking both natural and biological processes to address the "clean water gap". For example, the Water Abundance $X$-Prize challenges teams to develop renewable-powered technologies that harvest fresh water from air. ${ }^{5}$ It turns out numerous technologies can meet water production and energy demand targets, but to do so affordably is challenging.

Could human-engineered renewable energy-powered water reuse and desalination provide the answer? Partly, perhaps, in certain locations. But this does not address the need to clean up vast existing fresh water sources that are contaminated, for example, with nitrates and pesticides from agricultural runoff, with arsenic from natural origins, or heavy metals and organic solvents from industrial activities. Also, ignoring the high cost of implementation, for many developing countries there is abundant fresh water, but the challenge is to reliably disinfect it to prevent waterborne diseases that can devastate populations: diarrheal disease, hepatitis $A$, cholera, botulism, typhoid, etc.--diseases that are caused by protozoa, viruses, bacteria, and intestinal parasites.
Much attention is rightly placed on access to clean water in the developing world, while in California (the World's sixth largest economy) ${ }^{6}$ there is concern regarding a lack of clean drinking water in some rural communities. ${ }^{7}$ As a result, California is the only U.S. state to legally recognize a human right to water. Clean water supply is not an issue limited to third world and developing countries only; understanding the problems, and solutions to these problems, are needed the world over.

The last half century has seen the emergence and growth of numerous trends in water use, policy, research, and investment, including (1) water as a human right; ${ }^{8}$ (2) "virtual water" ${ }^{\prime \prime}$ and estimates of the water footprint of everything ${ }^{10}$ and anyone; ${ }^{11}$ (3) mainstream application of water desalination and reuse; ${ }^{12}$ (4) first came "energy for water and water for energy", ${ }^{13}$ then the "energywater nexus", 14 and now the "food-energy-water nexus"; ${ }^{15}$ (5) the "one water" movement; ${ }^{16}$ (6) decentralized water and wastewater treatment; ${ }^{17}$ (7) wastewater as a resource; ${ }^{18}$ and (8) water-focused investment funds ${ }^{19}$ and venture capital funds. ${ }^{20}$ In addition, water as a topic is highly newsworthy, and there is wide and deep interest in all aspects of the subject, spanning the natural and social sciences.

It is hard to understate the importance of a clean water supply. Research into treatment processes and how to effectively manage and distribute water is a dynamic landscape and there are various scientific journals that cater specifically for water-related research. So, why do we need npj Clean Water? As identified in the previous discussion, the importance of a clean water supply is clear, as is the criticality of research; the number of papers in this field increases year-on-year (which will continue), and npj Clean Water aims to report some of the best of these to the scientific community. Specifically, the journal is looking for important advances for the clean water research communities, which significantly extend understanding or capability. This includes original research papers that report new treatment processes, or noteworthy refinement and improvement of existing ones, via physical, chemical, and biological processes, as well as thoughtprovoking and critical reviews of the literature. Moreover, the journal will publish research and perspective pieces on water management policy; as discussed above, the natural sciences alone will not solve the clean water problem, and effective water management is crucial. Presenting these two aspects side-by-side in a single journal is therefore not only appropriate, but vital for a complete treatment of clean water-related research. In addition, by providing considered editorial selection of papers published, and a comprehensive peer review process, we aim to present high-quality works to the community.

npj Clean Water will publish all papers under an Open Access license type. Clean water supply is a global issue and we passionately believe that research on this topic should be widely and freely available to the research community, as well as to the policy makers whose decisions are informed by scientific output, and to the global population who ultimately stand to benefit from the studies reported.

We are truly excited to present to the research community $n p j$ Clean Water, and are delighted to be "turning on the taps" to a new forum for the dissemination of important works that address the societal issue of a clean water supply. 


\section{ADDITIONAL INFORMATION}

Competing interests: The author declares no competing interests.

Publisher's note: Springer Nature remains neutral with regard to jurisdictional claims in published maps and institutional affiliations.

Eric M. V. Hoek ${ }^{1,2}$

${ }^{1}$ Department of Civil \& Environmental Engineering, University of California, Los Angeles, CA 90095, USA and ${ }^{2}$ Water Planet, Inc., $721 \mathrm{~S}$.

Glasgow Ave., Los Angeles, CA 90301, USA

Correspondence: Eric M. V. Hoek (emvhoek@ucla.edu)

\section{REFERENCES}

1. https://sustainabledevelopment.un.org/?menu=1300. Accessed 24 March 2018.

2. Bazargan, A. (ed.) A Multidisciplinary Introduction to Desalination (Riverpress Publishers, The Netherlands, 2018).

3. http://www2.worldwater.org/data.html. Accessed 25 March 2018.

4. Sato, T., Qadir, M., Yamamoto, S., Endo, T. \& Zahoor Agricultural Water Management Vol. 130, 1-13, https://doi.org/10.1016/j.agwat.2013.08.007 (2013).

5. https://water.xprize.org. Accessed 23 March 2018.

6. http://fortune.com/2016/06/17/california-france-6th-largest-economy/. Accessed 23 March 2018.

7. http://innovation.luskin.ucla.edu/content/2017-impact-report. Accessed 23 March 2018.

8. Scanlon, J., Cassar, A. \& Nemes, N. IUCN - The World Conservation Union (2004) Water as a Human Right? IUCN Environmental Policy and Law Paper No. 51 (The International Union for Conservation of Nature and Natural Resources, Gland, 2004).

9. Allan, J. A. Virtual water: a strategic resource. Ground Water 36, 545-546 (1998).

10. Hoekstra, A.Y., Chapagain, A.K., Aldaya, M.M. \& Mekonnen, M.M. The Water Footprint Assessment Manual: Setting the Global Standard (Earthscan, London, 2011).
11. http://waterfootprint.org, https://www.easycalculation.com/other/waterfootprint-calculator.php, https://www.watercalculator.org. Accessed 21 March 2018.

12. Tapping the Oceans, The Economist: Technology Quarterly (2008). https://www. economist.com/node/11484059

13. Gleick, P. H. Water and energy. Annu. Rev. Energy Environ. 19, 267-299 (1994).

14. U.S. D.O.E. Report. The Water-energy Nexus: Challenges and Opportunities. https:// www.energy.gov/sites/prod/files/2014/06/f16/Water\%20Energy\%20Nexus\% 20Report\%20June\%202014.pdf. Accessed 21 March 2018 (2014).

15. Abraham, M. Introduction to the special section on the food, energy, water nexus. Environ. Progress. Sustain. Energy 37, 20 (2018).

16. http://uswateralliance.org/one-water. Accessed 21 March 2018.

17. http://www.water4point0.com. Accessed 21 March 2018.

18. Sutton, P.M., Rittmann, B.E., Schraa, O.J., Banaszak, J.E. \& Togna, A.P. Wastewater as a resource: a unique approach to achieving energy sustainability. Water Sci. Technol. 63, 2004-2009 (2011).

19. https://seekingalpha.com/article/4047417-investing-water-putting-together. Accessed 21 March 2018.

20. http://www.xpvwaterpartners.com. Accessed 21 March 2018.

(C) Open Access This article is licensed under a Creative Commons (c) Attribution 4.0 International License, which permits use, sharing, adaptation, distribution and reproduction in any medium or format, as long as you give appropriate credit to the original author(s) and the source, provide a link to the Creative Commons license, and indicate if changes were made. The images or other third party material in this article are included in the article's Creative Commons license, unless indicated otherwise in a credit line to the material. If material is not included in the article's Creative Commons license and your intended use is not permitted by statutory regulation or exceeds the permitted use, you will need to obtain permission directly from the copyright holder. To view a copy of this license, visit http://creativecommons. org/licenses/by/4.0/.

(c) The Author(s) 2018 